\title{
RECURSOS ADMINISTRATIVOS NO DIREITO COMPARADO: BRASILEIRO E ARGENTINO
}

\author{
"O que me preocupa é fazer com que o mundo faça sentir." \\ Willian McNeill
}

\section{Márcia Fratari Majadas ${ }^{1}$}

1. Introdução - 2. Consideraçōes sobre a Lei $9.784 / 99$ - 3. Apreciação sobre as leis da Argentina - 4. Importância da Lei $9.784 / 99$ no direito comparado Argentino - 5. Recursos: Revisáo total ou parcial de atos administrativos - 6. Fundamentos do direito comparado no recurso administrativo - 7. Classificação dos recursos segundo a Lei 9.784/99 - 7.1 Modalidades - 7.1.1. Representação - 7.1.2. Reclamação - 7.1.3. Pedido de Reconsideração -8 . Procedimentos dos recursos administrativos no direito argentino - 8.1 Recurso de Reconsideração - 8.2. Recurso Hierárquico - 8.3. Recurso de Alçada - 8.4. Recurso Extraordinário de Revisão - 8.5. Recurso de Revisão - 8.6. Outras Vias Administrativas 8.6.1. Queixa - 8.6.2. Retificação de Erros Materiais - 8.6.3. Aclaratória - 9. Efeito do recurso no direito comparado - 9.1. Efeitos Gerais do Recurso - 9.2. Tutela Preventiva - 10. Requisitos dos recursos no direito comparado - 10.1. Requisito Formal - 10.2. Requisito Material - 11. Prazos do recurso - 11.1. A Legitimaçāo Recursal no Direito Comparado - 11.2. Revisão Ex Officio na Lei Federal 9.784/99 - 11.3. Recurso Revogação na Lei Federal 9.784/99 - 12. PRAZOS PARA INTERPOSIÇÃO DE RECURSO - 12.1. Prazos Processuais no Direito Brasileiro - 12.2. Prazos no Direito Argentino - 13. Conclusões - 14. Referências bibliográficas

1 Mestranda em Direito, Área de Concentração: Sistemas de Resolução de Conflitos, da Universidade do Estado de Minas Gerais - Campus Fundacional de Ituiutaba. 


\section{Introdução}

A juridicidade e a atividade administrativa, em toda sua plenitude, gozam de privilégio especial e necessário, a presunção de sua legitimidade. É necessário que essa atividade seja, realmente, legítima e admissivel para obrigar os administrados a cumprirem os mandados e resoluções que dela resultem.

A necessidade de juridicidade e da atividade administrativa surge como uma consequiência natural do estado de direito, no qual se estabelece a supremacia da lei que fundamenta e sustenta toda a ação dos poderes do Estado. GARCIA, Oviedo ${ }^{2}$ assinala: las exigencias proprias de un estado de derecho imponen a la administración un régimen jurídico que ordene su vida y, al proprio tiempo, garantice a los particulares sus situaciones jurídicas frente al obrar de aquélla.

A Administração Pública estrutura-se no princípio da legalidade; princípio esse que expressa a liberdade do indivíduo na sociedade atual e relaciona-se com a administração, na medida em que a norma se conforma com a lei, face à submissão aos órgãos do Estado; o que diminui a possibilidade de arbitrariedades.

Outro fundamento da juridicidade e da atividade administrativa, a administração pública, tem papel prevalente de direitos que se pode exercer ao procurar dar cumprimento às finalidades de interesse geral, sem perder de vista que os particulares têm, também, direitos reconhecidos e garantidos por uma ordem constitucional, que não podem ser violados, sem que se dê lugar à ação tendente a lograr seu restabelecimento.

Nos países de jurisdição una, o contencioso administrativo não é admitido. Entretanto, é necessário diferenciar o processo administrativo, admitido nesses países, do processo jurisdicional administrativo, que envolve funçōes diferentes administração e jurisdição. A diferença pode ocorrer na finalidade; a função administrativa visaria ao fim do próprio Estado, ao interesse público, em primeiro lugar o Estado, enquanto que a jurisdicional atenderia ao objetivo do interessado no ato jurisdicional, ao interesse das partes, primeiro o indivíduo.

Entretanto, a diferença fundamental reside no fato de que, no processo administrativo, não se fala "em coisa julgada", a não ser administrativa; em relação ao processo jurisdicional administrativo, há de se falar "em coisa julgada", decisão última e irreformável.

No processo administrativo, há, sempre, a possibilidade de se rediscutir o assunto via judiciária, enquanto que, no processo jurisdicional administrativo, as decisões ulteriores são definitivas, pois, são decisões judiciais.

No Brasil, a Lei Federal 9.784, de 29.1.1999, estabeleceu normas básicas sobre o processo administrativo, no âmbito da Administração Federal direta e indireta, em especial à proteção dos direitos dos administrados e ao melhor cumprimento dos fins da Administração - artigo $1^{\circ}$. Essa lei é aplicável aos órgãos dos Poderes Legislativo e Judiciário da União, quando no desempenho de função administrativa. Contempla a Lei os princípios da legalidade, finalidade, motivação, razoabilidade,

2 GARCIA, Oviedo. Derecho administrativo. Madrid: 1959. t. I. p. 619. 
proporcionabilidade, moralidade, ampla defesa, contraditório, segurança jurídica, interesse público e eficiência.

Por outro lado, é assegurado ao administrado o direito de ser tratado com respeito pelas autoridades e funcionários, ter ciência da tramitação e dos termos de processos em que esteja na condição de interessado, formular alegações e apresentar documentos, antes da decisão, e fazer-se assistir por advogado, artigo $3^{\circ}$.

No direito de integração ${ }^{3}$, sob a ótica do direito comparado, cabe ressaltar as coincidências existentes entre a regulamentação dos procedimentos administrativos do Brasil e da Argentina, no que se refere aos princípios aplicáveis.

Pelo Tratado de Assunção, a regulamentação do procedimento administrativo, em geral, e dos recursos administrativos, em particular, não está alheia à construção do Direito da Integração. No entanto, é necessário que harmonizem as normas, mediante a superação das diferenças entre os órgãos do Mercosul, com vista à gradativa adequação das legislações.

\section{Considerações sobre a Lei $9.784 / 99$}

Promulgada, em 29 de janeiro de 1999, a Lei 9.784, que regula o processo administrativo no âmbito da Administração Pública Federal, prescreve o processo como forma de atuação da Administração Pública, via institutos e princípios que regem o direito administrativo, além de regular preceitos do Direito Processual como meio para o Administrador Público atingir os fins a serem alcançados.

O processo administrativo federal surgiu em virtude da inexistência de um sistema unitário, em relação aos processos administrativos, face a cada uma das pessoas políticas da Federação, por força de sua autonomia e capacidade de autoadministração, com evidente conveniência para os administrados, que enfrentaram, em diversas ocasiões, condutas ilegais e arbitrárias, por não existirem regras para os processos; pois, todo o poder de decisão, sempre, se concentrou no Poder Público.

O capítulo XV da Lei 9.784/99 estabeleceu a regra de que das decisões administrativas cabe recurso, face às razões de legalidade e de mérito - artigo 56 -, e dispõe, que o recurso administrativo tramitará, no máximo, por três instâncias administrativas, salvo disposição diversa.

De acordo com o disposto no artigo 59 da Lei $9.784 / 99$, o prazo para interposição de recurso administrativo é de dez dias, contados a partir da ciência ou divulgação oficial da decisão recorrida. Em caso de a lei não fixar prazo diferente, o recurso deverá ser decidido no prazo de trinta dias, a partir do recebimento dos autos pelo órgão competente; prazo esse que poderá ser prorrogado por igual período, ante justificativa explícita.

No teor do artigo 60 da Lei 9.784/99, o recorrente deverá expor os "fundamentos do pedido de reexame" do ato impugnado. O recurso, via de regra, não tem efeito

3 DELPIAZZO, Carlos E. Alcances y limites del Derecho de la Integración. In: De Derecho Público. Montevidéu: 1998. n.13. p. 45 e 51. 
suspensivo. No entanto, poderá a Administração, de ofício ou a pedido do interessado, dar efeito suspensivo ao recurso, quando houver justo receio de prejuízo de difícil ou incerta reparação - artigo 61 da Lei 9.784/99. Quanto ao julgamento recursal, o órgão competente do recurso poderá confirmar, modificar, anular ou revogar, total ou parcialmente, a decisão recorrida - artigo 64 da Lei 9.784/99.

A Lei $9.784 / 99$ não estabeleceu norma de processo administrativo, como"processo contencioso administrativo", e nem tribunais ou órgãos de julgamento "administrativos ligados ao Poder Judiciário". Isso porque, nos países de jurisdição una, o processo jurisdicional administrativo não foi acolhido pela legislação. Nesse sentido, assinala STASSINOPOULOS ${ }^{+}$que:

Embora o processo administrativo para a criação do ato administrativo não seja exclusividade do direito brusileiro. os estudos do direito comparado em geral cuidam do que é denominado de "processo contencioso administrativo", instituto que não existe no direito brasileiro e que se relaciona no que usualmente é denominado entre nós de jurisdição administrativa.

Torna-se necessário diferenciar processo administrativo de processo jurisdicional administrativo, uma vez que envolvem funções diferentes no âmbito da administração e jurisdição. A diferença está em que não se pode falar “em coisa julgada”, a não ser administrativa. No processo jurisdicional administrativo, "há coisa julgada", decisão última e irreformável. Nesse sentido, a lição de MUKAI ${ }^{5}$ :

No processo administrativo há sempre possibilidade de se rediscutir o assunto na via judiciária, enquanto que no processo jurisdicional administrativo as decisões últimas são definitivas, posto que elas próprias já são decisões judiciárias.

O diploma legislativo, em análise, volta-se à produção do ato administrativo: tanto do ato sancionador como, também, do ato ablativo, que cria direito aos particulares e, ao tratar da vontade administrativa, considera que "os atos da Administração serão precedidos de procedimento adequado à sua validade e à proteção dos direitos e interesses particulares" - artigo $1^{\circ}$ da Lei 9.784/99. Com esse entendimento, preleciona DALLARI ${ }^{6}$ :

Que logo no artigo $1^{\circ}$ da Lei Federal é afirmado que a lei estabelecerá normas básicas de Direito Administrativo visando à proteção dos direitos

+ STASSINOPOULOS, Epaminondas P. "Derecho comparado: uma nota sobre el procedimiento administrativo em Europa Ocidental". El procedimiento administrativo em el derecho comparado. Madrid: Editorial Civitas. 1993. pp. 503-504.

5 MUKAI. Toshio. A Lei do Procedimento Administrativo Federal. (Lei 9.784, de 1999) In: Revista Trimestral de Direito Público. São Paulo: Malheiros Editores. n. 27. 1999. p. 11.

6. [Adilson de Abreu] Dallari, Jornal do Adiogado. Jun. de 1999. p. 25. $4^{\text {a }}$ coluna. 
dos Administrados e ao melhor cumprimento dos fins da Administração. Isso significa que a lei é feita para o particular se defender dos abusos da Administração, mas é feita, também, para que a Administração melhor atinja seus fins.

A lei é aplicável aos órgãos dos Poderes Legislativo e Judiciário da União, quando no desempenho de função administrativa $-\S 1^{\circ}$ do artigo $1^{\circ}$ da Lei $9.784 / 99$. Portanto, a Administração Pública deve expedir seus atos mediante processo adequado e correspondente, por exemplo: convocação de servidores públicos via concurso público; contratação de empresas para construir determinada obra ou fornecer dado equipamento - processo licitatório; a apuração do servidor faltoso - processo faltoso; pedido de renovação de licença, também, deve ser precedido de processo.

Esse modelo processual do comportamento administrativo visa ao resultado e ao fim do processo realizado naquela esfera de Poder, conforme norma jurídica e princípios do Direito Administrativo, em obediência aos direitos dos particulares. Isso porque os atos "discricionários" e as invasões de competência, decorrentes da incontrastabilidade da atuação administrativa, inscrevem-se no espaço de racionalizar o Poder. Acentua SESIN?

La libertad estatal desenfreada, la desviación de poder, la arbitrariedad, el excesivo autoritarismo y todo tipo de abuso discrecional administrativo, importam graves ilegitimidades que los órganos jurisdicionales competentes deben declarar. Pero en verdad ello no es discrecionalidad'sino infración al orden jurídico administrativo, razón por la cual tales desviaciones no pueden senir para sustentar posturas que nieguen o resten transcendência al fenómeno en consideración.

Assim, a postura do juiz, para decidir ou não a respeito de um ato administrativo, é verificar se é discricionário; sendo discricionário, se a opinada escolha administrativa é válida, em função dos valores da ordem jurídica. O que importa, perante o Poder Judiciário, é discernir a jurisdicidade ampla do ato administrativo: se "inválida", "ilegítima" ou "injurídica".

Além disso, há de considerar-se que o esgotamento das vias administrativas, para ingresso na judicial, não é óbice ao imediato acesso à esfera jurisdicional. O esgotamento da via administrativa viabiliza o controle jurisdicional do ato administrativo.

Embora os princípios norteadores da Administração Pública, no Estado Brasileiro, não podem se desviar daqueles previstos no artigo 37 da Constituição Republicana, o atuar administrativo pode ser manejado, diferentemente, para cada esfera administrativa federada, de acordo com suas próprias e peculiares necessidades ou facilidades.

7 SESIN, Domingo Juan. Administracion Pública. Actividade Reglada, Discrecional y Técnica

- Nuervos Mecanismo de Control Judicial. Buenos Aires: Depalma. 1994.p. 102. 
A lei nacional de procedimentos administrativos da Argentina, 19.549, e Decreto Regulamentador $1.759 / 72$. modificado pelo Decreto $1.883 / 91$, estrutura o sistema administrativo federal do Estado Argentino, junto ao ordenamento administrativo da nação, dá lugar aos ordenamentos administrativos estaduais, em decorrência da Constituição Nacional que declara, em seu "Artículo 1: La Nación Argentina adapta para su gobierno la forma representativa republicana federal, según la establece la presente constitución".

Dispõe o artículo $5^{\circ}$ da Carta Política Argentina que:

"Artículo 5: Cada provincia dictará para si una Constitución bajo el sistema representativo republicano, de acuerdo con los principios, deda raciones y garantias de la Cosntitución Nacional, y que assegure su administración de Justicia, su régimen municipal, y la educación primaria. Bajo de estas condiciones, el Gobierno federal garante a cada provincia el goce y, ejercicio de sus instituciones".

Sob essas condições, o Governo Federal garante a cada Estado o gozo e exercício de suas instituições.

Edita o artigo 121 da Constituição Nacional: Las provincias conservan todo el poder no delegado por esta Constitución al Gobierno federal, y el que expresamente se hayan reservado por pactos especiales al tiempo de su incorporación.

Cada Estado Argentino conta com sua própria Lei de Procedimentos " (...) é essencialmente um direito local, isto é um direito estadual", segundo MARIE$\mathrm{NHOFF}^{8}$. Porém, a Nação goza de todas as prerrogativas de caráter administrativo, do mesmo modo que as províncias, em suas respectivas esferas, como está implícito na Constituição Nacional da Argentina.

Vale acentuar: o acesso à jurisdição e revisão do procedimento administrativo possui legitimidade constitucional e pode revisar toda e qualquer decisão administrativa, destinada a tornar mais efetiva a tutela dos interesses públicos, segundo decisão da Corte Suprema de Justiça da Nação.

As decisões adotadas no procedimento administrativo argentino não possuem caráter definitivo e os atos emanados da Administração devem ser revisados, em sede judicial.

Os procedimentos administrativos, segundo o texto da Lei Argentina, são princípios básicos que asseguram aos interessados as garantias constitucionais do devido processo, como requisitos essenciais do ato administrativo, de sua estrutura, validez e eficácia.

8 MARIENHOFF, Miguel. Tratado de Derecho Administrativo. Buenos Aires: Ed. Abeledo Perrot. t. I. 1995. p. 160. 
No trâmite processual, estão incluídos os recursos administrativos que devem ser considerados como matéria da esfera das lei constitucionais, referentes aos Poderes Executivo e Legislativo.

Acresce frisar: os recursos administrativos e o controle dos atos administrativos devem ser entendidos com simplicidade; pois, facilitam aos interessados a defesa de sua pretensão, inicialmente, lesionada.

Os recursos administrativos, na Argentina, podem ser fundados em razões vinculadas à legitimidade, à oportunidade, ao mérito e à conveniência do ato e do interesse público.

Sob a ótica do direito comparado, anotam-se as coincidências entre a regulamentação dos procedimentos administrativos do Brasil e da Argentina, no que se refere aos princípios aplicáveis.

Na Argentina, a Lei Nacional de Procedimento Administrativo - 19.549 -, alterada pela Lei 21.986 , acompanhada do regulamento de procedimentos administrativos, aprovado pelo Decreto 1.759 , de 3 de abril de 1972, e suas alterações posteriores, consolidadas no texto do Decreto 1.853 , de 17 de dezembro de 1991, reconhece, expressamente, os princípios da oficialidade, celeridade, economia, simplicidade e eficácia, do informalismo e devido processo, em suas diferentes manifestações, conforme CASSAGNE ${ }^{9}$.

Conclui-se que a regulamentação do procedimento administrativo, em geral, e dos recursos administrativos, em particular, não está alheia à construção do Direito da Integração. No entanto, é preciso superar as diferenças entre os órgãos do Mercosul, mediante a harmonização das normas, para a adequação gradativa das legislaçōes.

\section{Importância da Lei $9.784 / 99$ no direito comparado argentino}

Deve-se marcar a importância que a Lei $9.784 / 99$ trouxe para o desenvolvimento do direito administrativo brasileiro, no âmbito do direito interno e do emergente direito de integração, resultante do Mercosul. Quanto ao primeiro aspecto, sua aplicação deve ser feita a partir dos princípios gerais do direito administrativo legalidade, ampla defesa, contraditório, segurança jurídica, interesse público e eficiência - e dirigida à figura do administrado.

Sob o prisma do novo direito de integração, sobrelevam-se as coincidências entre a regulamentação dos procedimentos administrativos entre Brasil e Argentina.

A Lei Nacional de Procedimento Administrativo, 19.549, artículo 1. A; b e c, com suas respectivas alterações, reconhece, expressamente, os princípios da oficialidade, celeridade, economia, simplicidade e eficácia, do informalismo e devido processo, em suas diferentes manifestações.

9 CASSAGNE, Juan Carlos. Derecho Administrativ'o. Buenos Aires. Abeledo Perrot. 1996. t. II. p. 317 e ss. 
Ainda, assim, é necessária, no processo de integração, " a harmonização de normas, não só mediante a superação de diferenças entre os órgãos do Mercosul, mas também a adequação das legislações internas pelos Estados”, na lição de DELPIAZZO ${ }^{10}$.

$\mathrm{O}$ artigo $3^{\circ}$ da Lei $9.549 / 99$ assegura ao Administrado o respeito pelas autoridades e funcionários. o direito de ter ciência da tramitação e dos termos do processo, em que esteja na situação de interessado, além de formular alegações, apresentar documentos e fazer-se assistido por advogado.

\section{Recursos: revisão total ou parcial de atos administrativos}

$O$ recurso materializa o mecanismo que permite aos interessados postularem a revisão total ou parcial de determinado ato.

Constituem elementos do recurso: interesse que conduz à interposição para obter reforma, total ou parcial, de determinado ato contrário ao interesse do recorrente; deflagração, que consiste na provocação do órgão superior pela pessoa física ou jurídica para novo pronunciamento.

Consequientemente, o recurso resulta da promoção de atividade do interessado, com o alvo de reformar o ato hostilizado, para atender ao seu interesse. Exige um conjunto de normas, que servem para disciplinar o procedimento a ser adotado.

Recursos administrativos, segundo CARVALHO FILHO ${ }^{11}$, são os meios formais de controle administrativo, através dos quais o interessado postula, junto a órgãos da Administração, a revisão de determinado ato administrativo.

Para CRETELLA JUNIOR 12 , recurso é o "remedium iuris" que consiste na provocação a reexame de um caso, na esfera administrativa, perante a mesma autoridade ou outra de superior hierarquia.

A administrativista MEDAUR ${ }^{13}$ averba que os recursos apresentam-se como um dos modos pelos quais a Administração é provocada a fiscalizar seus próprios atos, visando ao atendimento do interesse público e à preservação da legalidade.

Via de regra, mesmo que o recurso satisfaça ao interesse do recorrente, é indubitável que se constitui instrumento de controle e fiscalização da Administração Pública, face às questões de legalidade e mérito.

A tramitação dos recursos ocorre na esfera administrativa e abrange todos os órgãos administrativos integrantes dos Poderes fundamentais e estruturais das pessoas federativas.

10 DELPIAZZO, Carlos E. Armonización juridica e incorporación de nomas comunes al Derecho interno en el Mercosur. In: Derecho Administrativo. Buenos Aires: 1993. ano 5. n. 14. p. 603 e ss. 11 CARVAlho fILHO, José dos Santos. Manual de Direito Administrativo. 5 ed. Rio de Janeiro: Lumen Juris. 1999. p. 696.

12 CRETELla JUNIOR, José. Curso de Direito Administrativo. 8 ed. Rio de Janeiro: Forense. 1986. p. 654.

13 MEDAUR. Odete. Direito Administrativo Moderno. 2 ed. São Paulo: RT. 1998. 
No Direito Comparado, consoante acepção de $\mathrm{LASO}^{14}$, recursos são los distintos medios que el derecho estabelece para obtener que la administración, en via administrativa, revise un acto y lo confirme, modifique e revogue.

$\mathrm{O}$ autor compreende que só os recursos dirigidos contra os atos administrativos é que têm lugar na via administrativa. Exclui os que têm finalidade distinta, como os que removem um funcionário. Diferencia, ainda, os recursos administrativos das ações contenciosas. Os primeiros cumprem-se ante a administração que atua como tal. Resolve e decide, administrativamente, enquanto que as segundas são equacionadas mediante uma ordem jurisdicional. A resolução da ação é contenciosa, prevista na sentença.

Para o administrativista PÉREZ ${ }^{15}$, o recurso é como la impugnación de un acto administrativo ante un órgano de ese caráter.

Essa definição apresenta características diferenciadas do recurso administrativo, como:

a)impugnação, observação de um ato anterior com o propósito de que, mediante um novo procedimento, a administração se pronuncie sobre a nulidade, anulação ou reforma;

b)dirigido contra um ato administrativo, incluindo-se, aqui, aqueles procedimentos que têm por finalidade outros efeitos distintos, tais como, a observação da conduta de um funcionário;

c) requerido por via administrativa, ante o mesmo órgão que editou o ato impugnado. Quando impetrado ante um órgão independente. distinto da administração, tem o caráter de recurso de ação contenciosa.

Para BIELSA ${ }^{16}$ es recurso administrativo todo medio de sustancia jurisdicional com el cual se defiende un derecho subjetivo o un interés legítimo. Essa definição, formulada em sentido lato, pressupõe todo meio destinado a contribuir com a revisão de um ato administrativo, que só se faz por meio do recurso administrativo. Bielsa destaca, como exemplo, a denúncia e a mera reclamação.

De acordo com esse conceito, admite-se que os recursos administrativos podem decidir, tanto para defender um direito em sentido estrito - recurso subjetivo como para defender um interesse legítimo - recurso objetivo.

Todas essas definições sustentam que o recurso administrativo é um direito dos sujeitos que pleiteiam a garantia constitucional de defesa, direito público subjetivo, diferente daquele cuja proteção se pleitear. $O$ recurso administrativo. para referir-se ao ato jurídico de uma manifestação da vontade, consiste em que seja proferido novo ato para revogar, modificar ou substituir o ato lesivo praticado, ou ainda, pode ser um meio de reação, impugnação ou defesa, do qual pode se valer o administrado para obter a revisão de um ato da esfera administrativa.

Assim, pode-se dizer que recurso administrativo é o conduto que a norma legal estabelece para os atingidos por ato administrativo defenderem direitos ou interesses,

14 LASO, Enrique Sayagués. Tratado de Derecho Administrativor. Montevidéu: t. II. 1959. p. 471.

15 PÉREZ. González Jesus. Los recursos administrativos. Madrid: 1960. p. 21.

16 BIELSA. Rafael. Derecho administrativo. Buenos Aires: I. IV. 1947. p. 303. 
mediante a interposição de ato ou requerimento para que a Administração o reconsidere na esfera administrativa e emane novo ato administrativo.

\section{Fundamentos do direito comparado no recurso administrativo}

Os recursos administrativos fundamentam-se: a) no sistema hierárquico, por via do qual a estrutura administrativa se organiza em escalonamento vertical de órgãos e agentes públicos. O poder de revisão ou de autotutela da Administração faculta a revisão ou reforma dos próprios atos administrativos, face à posição mais elevada na estrutura administrativa; b) no direito de petição, assegurado pela Constituição como garantia constitucional - artigo $5^{\circ}$, XXXIV. Esse direito permite que qualquer pessoa formule postulação aos órgãos públicos. Cabe-lhes apreciar e decidir, considerando o interesse público; c) no direito do contraditório e da ampla defesa artigo $5^{\circ}, \mathrm{LV}$, da Constituição da República. $\mathrm{O}$ referido dispositivo assegura aos litigantes, em processo administrativo ou judicial, e aos acusados em geral, o contraditório e ampla defesa, "com os meios e recursos a eles inerentes".

No Direito Comparado, o alicerce do recurso administrativo repousa na base hierárquica de uma boa organização administrativa.

Segundo $\mathrm{LASO}^{17}$, la jerarquia es la relación jurídica que vincula entre si los órganos de administración y los funcionários, mediante poderes de subordinación, para asegurar unidad en la acción. Essa unidade de ação é necessária para o bom desenvolvimento da atividade administrativa, resultante do fato de que todos os órgãos administrativos dependem de um órgão superior e único.

Dentre as múltiplas faculdades que tem a hierarquia, está a de revisar os atos prolatados pelos órgãos subordinados, podendo, no mérito, ser revisados, reformados, revogados ou substituídos por outros.

Evidencia-se que o apoio específico do recurso repousa na estrutura hierárquica da administração e na hierarquia administrativa, que possibilita ao órgão revisor, legalmente, competente exercer sua atividade de controle sobre os atos administrativos do órgão subordinado.

Um dos arrimos da juridicidade e da atividade administrativa, que a administração pública tem, é exercer o cumprimento de finalidades de interesse geral, sem perder de vista que os particulares, também, têm direitos reconhecidos e garantidos por uma ordem constitucional e que não podem ser violados, sem que se dê lugar a uma ação tendente ao seu restabelecimento.

No sistema institucional argentino, não se admite a existência de uma atividade administrativa livre de controle e isenta da necessária revisão, que não permita corrigir os desvios. Em consequiência, o controle administrativo funda-se na ordem jurídica estabelecida, na manutenção da seguridade por meio da lei, conforme o estabelecido na Constituição Nacional; o que possibilita uma realidade social concreta e determinada. 


\section{Classificação dos recursos segundo a Lei $9.784 / 99$}

A doutrina classifica os recursos administrativos em hierárquicos próprios e impróprios, segundo MEIRELLES ${ }^{18}$. Hierárquicos próprios são os dirigidos à autoridade imediatamente superior à que proferiu a decisão questionada, postulando sua reforma ou supressão. São interpostos perante a autoridade recorrida, a qual poderá reconsiderar o decidido, no prazo de cinco dias - artigo 56, § $1^{\circ}$, Lei 9.784/99.

Aliás, a Lei 9.784/99 ao estabelecer, no caput do artigo 56, que: Das decisões administrativas cabe recurso, em face de razões de legalidade e de mérito.

$\S 1^{\circ}$ - O recurso será dirigido à autoridade que proferiu a decisão, a qual, a não a reconsiderar no prazo de cinco dias, o encaminhará à autoridade superior.

$\S 2^{\circ}$ - Salvo exigência legal, a interposição de recurso administrativo independe de caução.

Desse modo o recurso será dirigido à autoridade que proferiu a decisão (e não à autoridade superior), extinguiu o recurso voluntário e criou o recurso de ofício sucessivo aos pedidos de reconsideração não atendidos. A Lei Federal mesmo trazendo uma alteração no conceito universal de "recurso" não ofendeu tal direito, pois a norma constitucional não foi afetada, apenas suprimiu o nomen juris (pedido de reconsideração), passando a englobá-lo no interior de um recurso de ofício", quando não reconsiderada a decisão.

Pelo disposto na Lei 9.784/99, o prazo para recurso, na esfera da União, é de dez dias, contados da ciência ou divulgação oficial da decisão recorrida - artigo 59 .

Se não houver prazo diferente em lei à autoridade caberá decisão, no máximo, em trinta dias, a partir do recebimento dos autos, prorrogáveis por igual período, ante justificativa explícita $-\S \S 1^{\circ}$ e $2^{\circ}$ do artigo 59 da Lei $9.784 / 99$.

Recurso Hierárquico impróprio, segundo MEIRELLES 19 , dá-se quando "a parte se dirige à autoridade ou órgão estranho à repartição que expediu o ato recorrido, mas com competência julgadora expressa, como ocorre com os tribunais administrativos e chefes do Executivo Federal, Estadual ou Municipal”. Tais recursos são admissíveis, apenas, quando houver previsão legal; não estão vinculados aos órgãos hierárquicos, mas destinados a órgãos hierárquicos para assuntos específicos.

\subsection{Modalidades}

Os recursos administrativos apresentam-se sob três modalidades: representação, reclamação e reconsideração.

\subsubsection{Representação}

A representação caracteriza-se pelas manifestações insurgentes não qualificáveis. Qualquer pessoa pode denunciar irregularidades ou condutas ilegais de agentes

18 MEIRELLES, Hely Lopes. Direito Administrativo Brasileiro. 18 ed.. São Paulo: Malheiros. 1993.

19 ob. cit. p. 581 . 
e órgãos administrativos. Segundo CARVALHO FILHO ${ }^{20}$, o ponto marcante desse recurso consiste em que o representante está exercendo seu direito de cidadania. não tendo, no mais das vezes, qualquer interesse direto no resiabelecimento da legalidade.

Alguns estudiosos não o consideram como recurso administrativo, mas, denúncia com o objetivo de alertar a autoridade competente para conduta administrativa censurável, prevista no artigo $74, \S 2^{\circ}$ da Constituição Federal.

Da decisão que não couber recurso hierárquico. cabe representação, no prazo de cinco dias úteis; como exemplo, o disposto no artigo 109, II, da Lei 8.666/93 sobre licitações e contratos.

\subsubsection{Reclamação}

Reclamação, na lição de GASPARINI"1 , consiste em: "oposição solene escrita e assinada, a ato ou atividade pública que afete direitos ou interesses legítimos do reclamante". Demonstra inconformismo do administrado face à decisão administrativa que lesa direitos ou interesses - Decreto 20.910, de 6.1.32. Se outro prazo não houver fixado em lei, prescreverá em um ano, a partir da data do ato ou fato do qual se originar - artigo $6^{\circ}$.

A reclamação administrativa suspende a prescrição. Constitui dever da Administração, conforme artigo 48 da Lei 9.784/99, decidir solicitaçōes ou reclamações em geral, no prazo de trinta dias, prorrogáveis, motivadamente. por igual período, após a competente instrução - artigo 49, Lei 9.784/99.

Os prazos começam a correr a partir da cientificação oficial, excluindo-se da contagem o dia do começo e incluindo-se o do vencimento. Caso coincida com dia em que não haja expediente ou seja encerrado antes da hora normal, prorrogar-se-á para o primeiro dia útil $-\$ 1^{\circ}$ do artigo 66 da Lei $9.784 / 99$. Se o prazo for expresso em dias, contar-se-á de modo contínuo (dia-a-dia). Se expresso em anos ou meses. contar-se-á de data a data, valendo como termo final o último dia do mês, quando nele não houver o dia equivalente ao inicial $-\$ \$ 2^{\circ}$ e $3^{\circ}$, artigo 66. Lei. 9.784/99.

\subsubsection{Pedido de Reconsideração}

Prolatada a decisão, no procedimento administrativo, a parte inconformada pode dela postular reconsideração perante a mesma autoridade, por via de petição fundamentada. ou, no prazo legal, ofertar razões recursais.

\section{Procedimentos dos recursos administrativos no direito argentino}

Os atos administrativos de alcance individual, bem como os de alcance geral, podem ser impugnados por meio de recursos administrativos. Os recursos podem

20 CARVALHO FILHO. José dos Santos. Manual de Direito Administrativo. 5 ed. Rio de Janeiro: Lumen Juris. 1999. p. 701.

21 GASPARINI. Diógenes. Direito Administrativo. 4 ed. São Paulo: Saraiva. 1995. p. 535. 
fundar-se tanto em razões vinculadas à legitimidade, como à oportunidade, ao mérito e à conveniência do ato impugnado em prol do interesse público.

\subsection{Recurso de Reconsideração - 84 usque 88 e 100 RPA}

Conforme o artigo 84 do Decreto $1.759 / 72$, pode-se interpor Recurso de Reconsideração contra todo ato administrativo definitivo, que impeça totalmente a tramitação da reclamação ou pretensão do administrado contra os interlocutórios ou de mero expediente que causem lesão a um direito subjetivo ou a um interesse legítimo.

Deverá ser interposto Recurso de Reconsideração no prazo de dez dias da notificação do ato, perante o mesmo órgão que o proferiu: o qual decidirá o recurso no prazo de trinta dias - artigo 86, Decreto $1.759 / 72$--, reputando-se, tacitamente, denegado, sem necessidade de requerer despacho.

O prazo começa a ser computado, se não produziu prova. desde o dia seguinte à imposição do recurso: se a produziu. haverá que se distinguir desde o dia seguinte à apresentação do arrazoado; desde o dia seguinte ao vencimento do trâmite para alegar sobre a prova, quando o particular não o faz.

O recurso é apresentado ao mesmo órgão. O órgão que decide é o que editou o ato impugnado: se o ato administrativo tiver sido ditado por delegação, o recurso será resolvido pelo órgâo delegado; se a delegação houver cessado no tempo da interposição do recurso, será resolvido pelo delegante.

Os motivos da impugnação podem ser: legitimidade, oportunidade, mérito ou conveniência.

\subsection{Recurso Hierárquico - artigos 84 a 93 RPA}

Prescreve o artigo 89 do Decreto $1.759 / 72$ que "o recurso hierárquico é cabível contra todo o ato administrativo definitivo ou que impeça totalmente o processamento da reclamação ou pretensão do administrado". Não é necessário ter sido interposto e nem fundamentar, novamente, o hierárquico.

Dispõe o artigo 90 do Decreto 1.759/72 que "o recurso hierárquico deverá ser interposto perante a autoridade que proferiu o ato no prazo de quinze dias contados a partir da notificação e será encaminhado de ofício no prazo de cinco dias ao Ministério ou Secretaria da Presidência ao qual o órgão emissor do ato esteja submetido". O prazo para decidi-lo será de sessenta dias - artigo 91, Decreto 1.759/72. São motivos de impugnação a legitimidade, a oportunidade, o mérito e a conveniência. (Artigo 73 do Decreto 1.759/72).

\subsection{Recurso de Alçada - artigos 94 ess}

Estabelece o artigo 94 do Decreto $1.759 / 72$ que será cabível "contra os atos administrativos definitivos ou que impeçam totalmente o processamento do requerimento ou pretensão do recorrente, emanados pelo órgão superior de um ente autárquico". Com base no artigo 97, o recurso de alçada poderá fundar-se tanto em 
razões de legitimidade, como de oportunidade, mérito ou conveniência. (Artigo 73 do Decreto 1.759/72).

$\mathrm{Na}$ hipótese de ser aceito o recurso, a decisão limitar-se-á a revogar o ato impugnado, podendo-se modificá-lo ou substituí-lo em caráter excepcional, desde que existam fundadas razões de interesse público que o justifiquem.

\subsection{Recurso Extraordinário de Revisão}

Com fulcro no artigo 22 da Lei 19.549 , lei nacional do procedimento administrativo argentino. a doutrina e jurisprudência admitem o recurso extraordinário de revisão de ato, se existirem contradições na parte dispositiva quando, após ter sido proferido, se readquirirem ou descobrirem novos documentos decisivos, cuja existência se ignorava; quando o ato a fundar em documentos falsos, ou quando tiver sido proferido mediante suborno, prevaricação, violência, qualquer outro artifício fraudulento ou com grave irregularidade.

A escolha da via judicial implica a perda da via administrativa, mas não impede a desistência em qualquer estado, a fim de promover a ação judicial.

O prazo é de quinze dias úteis, administrativos, desde a notificação do ato do qual se recorre. O prazo de resolução é de trinta dias úteis, administrativos. É apresentado perante o mesmo órgão que dita o ato, devendo ser enviado no prazo de cinco dias e de ofício ao Ministério ou Secretaria da Presidência da Nação. onde tramitará.

\subsection{Recurso de Revisão - Artigo 22 da Lei 19.549}

De caráter excepcional e restrito, o Recurso de Revisão procede contra atos administrativos definitivos que tenham o caráter de firmes. O prazo de interposição é de dez dias. quando houver contradição na parte dispositiva do ato impugnado, ou de trinta dias.

O recurso de revisão é um recurso autônomo, em relação aos recursos de reconsideração e hierárquico.

\subsection{Outras Vias Administrativas}

Queixa, retificação de erros materiais e aclaratória.

\subsubsection{Queixa - artigo 71 RPA}

A Queixa não representa recurso administrativo, uma vez que não existe, em seu objeto, a intenção de impugnar o ato administrativo - artigo 71, do Decreto $1.759 / 72$. Representa economia processual no procedimento administrativo, conforme artigo $1^{\circ}$, inciso " $b$ ", da Lei 19.549. O prazo de resolução é de cinco dias úteis, administrativos. Apresenta-se perante o órgão superior imediato, que a resolve. 


\subsubsection{Retificação de Erros Materiais - artigo 101 - Decreto $1.759 / 72$}

A Retificação de Erros Materiais não é caso de recurso administrativo, uma vez que não interrompe e nem possui prazo de interposição. É apresentada perante o órgão superior imediato ou o que ditou o ato; é resolvida pelo órgão superior.

Quanto ao prazo de resolução, se a retificação foi a pedido de particular, poderá haver denegação tácita ou silêncio e aplica-se o disposto no artigo 10 da Lei 19.549 . Para esse caso, o órgão tem prazo de três dias para fazer o ato retificatório - artigo 26 da Lei 19.549. LNPA; se não há petição, a Administração pode retificar o erro a qualquer momento.

\subsubsection{Aclaratória - artigo 102 RPA - Decreto $1.759 / 72$}

Sustenta a doutrina que a Aclaratória não é caso de recurso administrativo. Tem procedência contra os atos administrativos definitivos.

O prazo de interposição de Aclaratória é de cinco dias, apresentada ao mesmo órgão que ditou o ato; sendo ele responsável pela solução, no prazo de 10 (dez) dias.

Os motivos de impugnação ocorrem quando existe contradição entre a motivação e a parte dispositiva e quando se deve suprir omissão sobre questões suscitadas.

\section{Efeito do recurso no direito comparado}

\subsection{Efeitos Gerais dos Recursos}

São efeitos dos recursos o suspensivo e o devolutivo. No suspensivo, a interposição do recurso suspende, até a decisão final, os efeitos do ato hostilizado. No devolutivo, o recurso implica a apreciação integral da matéria questionada pelo órgão julgador e acarreta a substituição da decisão atacada, proferida pelo órgão que julga o recurso.

Impende anotar que todos os recursos possuem efeito devolutivo, pois possibilitam o exame integral do processo pelo órgão superior ${ }^{22}$. Salvo determinação legal expressa em contrário, o recurso não tem efeito suspensivo; porém, o parágrafo único do artigo 61 da Lei 9.784/99 prevê: "Havendo justo receio de prejuízo de difícil ou incerta reparação decorrente da execução, a autoridade recorrida ou imediatamente superior poderá, de ofício ou a pedido dar efeito suspensivo ao recurso". Mandamento válido no ordenamento brasileiro e argentino.

Enquanto que a regra para os recursos judiciais é a de que devem ter efeito suspensivo, para os administrativos é inversa porque possuem caráter de auto-executoriedade e devem ser colocados em imediata execução, independentemente de ordem judicial.

22 MARQUES, José Frederico. Manual de Direito Processual Civil. 2 ed. São Paulo: Saraiva. 1974. 
Contudo, nada obsta que, em determinados casos excepcionais, haja previsão normativa sobre o efeito suspensivo, na execução do ato, pela mera interposição de recursos. quando é conferido poder à Administração para suspendê-lo, tanto de ofício como a pedido do recorrente.

Nesse sentido, MEIRELLES ${ }^{23}$ preleciona: Os efeitos do recurso administrativo são normalmente o devolutivo e, por exceção, o suspensivo. Nesse mesmo entendimento DI PIETRO ${ }^{24}$ ensina: Eles (os recursos) podem ter efeito suspensivo ou devolutivo, este último é o efeito normal de todos os recursos, independendo de norma legal.

Pelo teor do artigo 61 da Lei 9.784/99 estabelece: "salvo disposição legal em contrário, o recurso não tem efeito suspensivo". A decisão atacada não terá a paralisação dos efeitos que deve produzir, em virtude do recurso interposto pelo interessado, a não ser quando julgado impróvido. Caso o recurso seja próvido, por decisão final, nenhum efeito poderá ter sido produzido pelo ato.

\subsection{Tutela Preventiva}

Não há dúvida de que pela regra da não-suspensividade os recursos administrativos, diante de certas situações, merecem tutela preventiva ou cautelar - Leis $8.437 / 92$ e $9.494 / 97$ - que visa resguardar direito do interessado e preveni-lo contra efeitos danosos de caráter irreparável.

Com essa finalidade, dispôs o artigo 61, parágrafo único da Lei 9.784/99, que, se houver ameaça de prejuízo de difícil ou incerta reparação, por força da decisão atacada, poderá a autoridade recorrida ou julgadora conferir efeito suspensivo ao recurso.

O pressuposto do efeito suspensivo configura-se na lei com o justo receio do interessado sofrer prejuízo de difícil ou incerta reparação, em decorrência da execução do ato impugnado.

O justo receio é de natureza subjetiva, enquanto que a ameaça reflete um juízo objetivo. Portanto, a ameaça tem que ser real, comprovada com dados concretos, e atual para permitir a tutela cautelar. Se o risco for antigo, não justifica postular a tutela preventiva.

No processo judicial. exige-se como pressuposto da tutela preventiva o periculum in mora (perigo na demora) e o fumus boni iuris (indícios do bom direito), ambos adequados à tutela preventiva, no processo administrativo. O periculum in mora retrata que a demora na solução final da questão pode não ser mais útil no acolhimento do recurso. Quanto ao fumus boni iuris, apesar de pendente o julgamento final do recurso, pode-se vislumbrar elementos que denotam que o pedido de suspensão dos efeitos não é temerário, mas, ao contrário, reveste-se de admissibilidade.

23 MEIRELLES. Hely Lopes. Direito Administrativo Brasileiro. 18 ed. São Paulo: Malheiros. 1993.

24 DI PIETRO. Maria Sylvia Zanella. Direito Administrativo. 3 ed. São Paulo: Atlas. 1993. 
A lei alude a prejuízo de difícil ou incerta reparação. O prejuízo é possível, mas será difícil repará-lo ou. ainda. pode-se constatar se será ou não reparado.

Consequientemente. é a autoridade recorrida que avalia a necessidade da interposição do efeito suspensivo do recurso ou a de nível superior, encarregada de apreciá-lo. À primeira cabe fazer o juízo de retratação sobre o ato de sua autoria. A autoridade decisória é aquela que apreciará o recurso interposto pelo interessado.

$\mathrm{O}$ efeito suspensivo do recurso pode decorrer da atividade provocada pelo interessado ou de ofício. No entanto. a lei permite, ante a constatação de risco, que a própria autoridade determine a suspensão dos efeitos da decisão recorrida, via ofício.

No direito comparado o regulamento argentino Decreto-Lei 1.759/72, autoriza a suspensão do prazo para recorrer. se o interessado solicitar vista das atuações.

Durante o tempo que se conceder a suspensão transitória, total ou parcial, da execução do ato impugnado, sempre que a mesma possa causar ao recorrente danos graves e que mencionada suspensão não acarrete perturbação grave aos interesses gerais ou aos direitos fundamentais de terceiro.

Como dispōe o artigo 61 da Lei Federal 9.748/99 e, também, o artigo 12 da Lei Nacional de Procedimento Administrativo da Argentina dispõem que "a Administração poderá de ofício ou a pedido da parte e mediante decisão fundada, suspender a execução por razões de interesse público ou para evitar prejuízos graves ao interessado. ou quando houver fundada alegação de alguma nulidade absoluta".

Por outro lado, sob o aspecto dos efeitos que acarretam a interposição de recursos, em face das atribuições conferidas ao órgão julgador. compete a obrigação de instituí-los e decidí-los.

A rigor, as atribuições da Administração, em relação ao conteúdo das decisões a serem proferidas nos recursos, dependem da validade ou invalidade do ato e da estabilidade ou instabilidade da situação jurídica que tenha criado.

Assim, se o ato impugnado é inválido, sua modificação ou revogação, em resposta ao recurso, é o comportamento esperado da Administração. Por outro lado, se $o$ ato é válido e a impugnação funda-se em razões de mérito, a Adninistração, ao decidir o recurso, depende de que a situação criada pelo ato tenha adquirido grande estabilidade. Se essa situação pode ser modificada discricionariamente pela Administração, do mesmo modo poderá decidir o recurso. Se a Administração não pode modificar discricionariamente o ato que criou a situação jurídica dotada de estabilidade, o recurso retira as restrições à mutabilidade do ato; mas, somente, nos termos da pretensão do recorrente.

\section{Requisitos do recurso no direito comparado}

O artigo 60 da Lei $9.784 / 99$ dispõe que os requisitos podem ser formais e materiais. 


\subsection{Requisito Formal}

Conforme o disposto no artigo 60 da Lei em comentário, o recurso deve ser apresentado por meio de requerimento escrito. Admite a lei que a petição recursal seja acompanhada de documentos para melhor apreciação da matéria, de forma a atender ao interesse do recorrente.

\subsection{Requisito Material}

O recorrente deverá expor os fundamentos do pedido de reexame, nos termos do artigo 60 da Lei 9.784/99. Os fundamentos do recurso são as razões que o recorrente deve apresentar para demonstrar à autoridade competente que a decisão recorrida merece reforma.

Aliás, os fundamentos do recurso são apresentados não só à autoridade superior à qual foi dirigido o recurso, mas também à autoridade que proferiu a decisão recorrida, uma vez que lhe é conferida a oportunidade de efetuar o juízo de retratação - artigo 56, $\$ 1^{\circ}$, Lei $9.784 / 99$.

De acordo com o inciso III do artigo 58 da Lei $9.784 / 99$, têm legitimidade para interposição de recurso administrativo as organizações e associações representativas, no tocante a direitos e interesses coletivos, e, também, as associações, quanto a direitos ou interesses difusos - inciso IV do mesmo artigo.

No Direito Argentino, para interposição de recursos administrativos os requisitos podem ser formais e substanciais, escusando os interessados da inobservância das exigências formais, não essenciais, e que podem ser cumpridas ulteriormente qualificação errônea de recursos, falta de data de notificação do ato impugnado ou a de apresentação do recurso. Estabelece o artigo 77 do Decreto Regulamentar 1.759/72 - consolidado em 1991 - que "poder-se-á ampliar a fundamentação dos recursos interpostos a qualquer momento antes de ser proferida a decisão". Se identificada alguma deficiência formal, o recorrente será intimado a saná-la em prazo peremptório, sob pena de desconsideração do recurso.

Há requisitos de índole formal que devem ser cumpridos: a) indicação do ato recorrido; b) apresentação escrita do recurso; c) assinatura do recorrente, com indicação dos dados pessoais, do domicílio real e da constituição do domicílio, no raio urbano de localização do organismo do qual emanou o ato recorrido; d) a petição deve ser clara e precisa; e) que se ofereça prova; $f$ ) que não se dirija a impugnação de um ato que causou dano, pois contra ele só cabem ações judiciais; g) que se dirija contra um ato administrativo, já que as medidas preparatórias, alegações e ditames não são recorríveis. Como requisitos substancias, o recurso deve ser interposto nos prazos fixados em lei e fundamentado.

A comparação do direito argentino com o brasileiro permite constatar, em ambos, a maior amplitude dos prazos para recorrer, em algumas hipóteses, e menor elasticidade dos prazos previstos para o pronunciamento dos órgãos públicos competentes; aspecto que devem ser considerados positivos do ponto de vista dos interessados. 
Segundo DELPIAZZO"25, "a forma para interposiçāo de recursos deve ser ordinariamente escrita, sem prejuizo das facilidades decorrentes das novas tecnologias de informação que possibilitem a apresentação via informática".

Quanto à fundamentação recursal, deve ser ofertada à autoridade competente na elaboração do contexto do pedido de recurso, podendo juntar os documentos que julgar convenientes - artigo 60 da Lei n. 9.784/99).

\section{Prazos do recurso}

No Brasil, as previsões da Lei 9.784/99, em matéria de recurso, inserem-se no controle da Administração Pública pelos administrados, segundo FIGUEIREDO ${ }^{26}$. Conforme o artigo 56, cabe recurso administrativo das decisões administrativas "em face de razões de legalidade e de mérito". Isso porque os atos administrativos "vinculados" e "discricionários" são passíveis de reexame na esfera administrativa. Embora entenda-se a discricionariedade como exercício de juízos subjetivos de conveniência e oportunidade do legislador, óbice algum poderá ser oposto a que a própria Administração Pública reveja o ato, em sede recursal.

Expressa, claramente, a lei que as razões do recorrente podem ser de legalidade ou de mérito. Quando o recorrente postula a revisão do ato, por jugá-lo contaminado de vício de ilegalidade, o recurso terá como base os fundamentos de legalidade para que seja restaurada.

Diante dos recursos administrativos, tanto merece atenção o bem público, o interesse geral, como o direito do administrado; porém, a Administração Pública não é absolutamente discricionária, mas subordinada ao princípio da legalidade, do qual não pode se afastar sob pena de incorrer em ato de improbidade.

Para qualquer reclamo de particular, em recurso contra ato administrativo, o critério dominante, na solução final do caso, estrutura-se e baseia-se no interesse do bem comum.

Quando o recurso fundar-se em razões de mérito, o administrador atuará em seu poder discricionário. Pode rejeitar ou acolher o recurso, conforme exigências pertinentes ao interesse público; isto é, a pretensão do recorrente será julgada conforme critérios de conveniência e oportunidade administrativas, próprias da atividade discricionária.

Os dois parágrafos do dispositivo acima citado tratam de questões de procedimentos do recurso. O parágrafo primeiro indica que o prolator da decisão recorrida é o órgão de interposição do recurso. Prevê, sempre, a possibilidade de reexame da decisão e, somente na negativa, o encaminhamento do recurso à autoridade superior,

25 DELPIAZZO, Carlos E. El procedimiento administrativo y los nuevas tecnologias de La información: In: Uruguaya de Derecho Constitucional y Político. Montevidéu: t. VIII. n. 48. 1992. p. 417 e ss.

26 FIGUEIREDO, Lucia Valle. Curso de Direito Administrativo. 4 ed. Malheiros Editores. Sāo Paulo. 2000 pp. 332 e 85. 
competente para seu julgamento; embora a Lei Federal não indique quem é a autoridade superior competente para o julgamento do recurso.

O parágrafo segundo institui a regra de que o recurso administrativo prescinde. para sua interposição, de oferecimento, de caução, salvo dispositivo legal em contrário.

Apesar da Lei 9.784/99 não prever, nominalmente, os tipos distintos de recurso administrativo. é evidente que admite não só a revisão pelo órgão que proferiu o ato, mas também por três instâncias administrativas - artigo 57 da Lei n. 9.784/99; o que caracteriza a adnissibilidade de interposição de. no máximo. dois recursos. de revogação e hierárquico. A regra estabelecida no artigo, considera a autoridade para a qual é dirigida o recurso como segunda instância: é admissível interpor mais um recurso para ser apreciado pela terceira instância.

No Direito Comparado, o artigo 24 da Lei 19.549 preservou duas espécies de impugnação de atos gerais: direta quando o controle da legalidade de um regulamento, por meio da impugnação direta, possibilita sua anulação geral. É considerada de máxima importância porque possibilita a eliminação de normas secundárias que infringem a lei.

Indireta quando no caso de impugnação indireta. em sede administrativa de disposições regulamentares, os recursos poderão fundar-se em razões vinculadas à legitimidade. à oportunidade, ao mérito ou à conveniência. (Artigo 73 do Decreto $1.759 / 72$ )

Quanto aos efeitos da impugnação indireta, considera-se que, embora, a decisão do tribunal só tenha alcance inter partes, a declaraçào de ilegalidade do regulamento tem, indiretamente, alcance erga omnes, uma vez que conheça que o regulamento é ilegal, a Administração deve proceder conforme o princípio da legalidade - deve derrogá-lo.

Dispõe o artigo 83 do Decreto Regulamentador $1.759 / 972$ que os atos administrativos de alcance geral poderão ser derrogados, total ou parcialmente, e substituídos por outros de ofício ou a pedido de parte e. ainda, mediante recurso nos casos em que for procedente.

Para a impugnação indireta, é necessária a existência de um ato individual, bem como a nulidade do regulamento.

\subsection{A Legitimação Recursal no Direito Comparado}

São legitimados para recorrer. no procedimento administrativo brasileiro, segundo o artigo 58 da Lei 9.784/99: I -- os titulares de direitos e interesses que forem partes no processo; Il - aqueles cujos direitos e interesses forem indiretamente afetados pela decisão recorrida; III - as organizações e associaçōes representativas no tocante a direitos e interesses coletivos; IV — os cidadãos ou associações quanto a interesses difusos e coletivos.

A distinção entre direito e interesse, no sistema brasileiro não foi instituída pelas leis ora em estudo. Nem sempre é possivel subjetivar um interesse em alguém determinado porque um mesmo interesse pertence a mais de um indivíduo, ao mesmo tempo. ou a todos, indistintamente, ao mesmo tempo. 


\section{Para ARRUDA ALVIM ${ }^{27}$ :}

"No Código do Consumidor, no artigo 82, embora os conceitos e campo de abrangência de "interesses" e direitos sejam diversos, justifica-se o emprego conjunto da expressäo pelo legislador brasileiro na medida em que se busca aumentar o rol dos bens juridicamente protegíveis".

Continua, ainda, o insigne Professor ... "há uma série imensa de interesses. para os quais. a defesa individual é praticamente inviável".

O inciso I do artigo 58 da Lei $9.784 / 99$ cuida da previsão do próprio interessado na relação processual administrativa em recorrer de decisão que seja contrária à sua pretensão.

O inciso II, a exemplo do que ocorre com o artigo 499 do CPC, prevê, como legitimados, os terceiros interessados, cujos direitos ou interesses forem, indiretamente. afetados pela decisão recorrida.

Contudo, a decisão pode afetar seus direitos e interesses, causando-lhes ônus e gravames. Para evitar novo processo, em que esses terceiros venham a pleitear a revisão da decisão, a lei legitimou-os para o oferecimento do recurso. No entanto, cabe aos interessados indiretos, indicar o efeito gravoso, advindo da decisão recorrida. Não havendo tal comprovação. o recurso não será conhecido - artigo 63. III, Lei $9784 / 99$.

Dispõe o inciso III do artigo 58 da Lei $9.784 / 99$ que as organizações e associações representativas, no tocante a direitos e interesses coletivos, possuem determinadas entidades representantes de grupos titulares de direitos transindividuais coletivos e têm idoneidade para defender os interesses de seus representados, no processo administrativo.

São legitimados, ainda, os cidadãos ou associações, quanto a direitos ou interesses difusos - artigo 58. IV, da Lei 9.784/99 - porque direitos difusos, também. são transindividuais, de natureza indivisivel: mas, não existe relação jurídica, base que marca os direitos coletivos. Pelo fato de que, por serem legitimados, a lei permite que procurem a tutela de direitos do próprio grupo ao qual pertençam.

O Direito Argentino, no texto da Lei 19.549 e seu decreto regulamentador, institui a legitimação do interessado, de forma mais plausível. respondendo ao mais moderno critério sobre a matéria. No procedimento administrativo, legitima-se a situação do interessado para promover o processo administrativo. Deverá assentar sobre base jurídica subjetiva, proveniente de direito exclusivo de uma situação particular, concorrente, lesionada por procedimento da Administração ao ditar um ato. Pode, também. legitimar-se como terceiro, chamado pela Administração de parte; pressupõe-se que houve lesão particular em sua situação.

Essa situação particular e o agravo ao recurso deverão justificar-se. pois a ação popular que lesiona interesses jurídicos gerais é a única que há de ser excluída.

27 ARRUDA ALVIM, Código do Consumidor Comentado. $2^{\mathrm{a}}$ ed. São Paulo. ed. RT 1995. pp. $364-65$. 
conforme dispõe o artigo 77: "el recurrente estimare como legítima para sus derechos o interesses". A última expressão demonstra que o recorrente tem interesse particular, pessoal, e que a reforma do ato será benéfica.

Para haver legitimidade, é necessário que a parte justifique o ato de agravo na interposição do recurso.

\subsection{Revisão Ex Offício na Lei Federal $9.784 / 99$}

Indica o artigo 63 da lei $9.784 / 99$ que o recurso não será conhecido, quando interposto: (I) fora do prazo; (II) perante órgão competente; (III) por quem não seja legitimado; (IV) após examinada a esfera administrativa tendo em vista que: "o não conhecimento do recurso não impede a Administração de rever de offício o ato ilegal. desde que não ocorrida a preclusão administrativa", parágrafo segundo do mesmo dispositivo.

Nesse entendimento, a lição de MEIRELLES ${ }^{28}$ : realmente, o que ocorre nas decisões administrativas finais é, apenas, preclusão administrativa, ou a irretroabilidade do ato perante a própria administração.

$O$ poder de revisão de ofício do ato da atividade administrativa fundamenta-se nos princípios da legalidade, boa fé, indisponibilidade do interesse público e finalidade. Por isso, trata-se mais de um poder-dever, do que de um simples poder e, sobretudo, no princípio da autotutela - Súmula 473 STF.

Nas hipóteses do recurso intempestivo - inciso I do artigo 63 -- ou de exaustão da esfera administrativa - inciso IV do artigo 63 - ocorrerá a preclusão administrativa, inclusive de coisa julgada administrativa. Assim, o parágrafo segundo do artigo 63 parece não apresentar nenhuma correlação com os incisos acima aludidos. O pressuposto fático de incidência - não ocorrência de preclusão administrativa não se configura nas hipóteses dos incisos I e IV do artigo 63; pois, sempre em tais casos terá ocorrido a preclusão.

O poder-dever de revisão do ato ilegal, tratado nas súmulas 346 e 473 do Supremo Tribunal Federal, há de ser analisado via processualização da atividade administrativa, com fundamento nos incisos LIV e LV, do artigo $5^{\circ}$ da Constituição da República.

Eis que a revisão da validade do ato administrativo, em decisão proferida em processo administrativo, em sede administrativa, por impulso de ofício ocorrerá, se fundado na infração da lei, com a participação de todos os interessados envolvidos. Qualquer ato administrativo goza de presunção de legalidade, contraditório, boa fé e segurança jurídica.

O recurso deverá ser interposto junto à própria autoridade que proferiu a decisão, no prazo de dez dias, contados a partir da ciência ou divulgação oficial da decisão recorrida. Cabe a esta, se não considerá-la em cinco dias, elevar a matéria ao superior

28 MEIRELLES, Hely Lopes. Direito Administrativo Brasileiro. 18 ed. São Paulo: Malheiros. 1993. 
que, para decidir, disporá de trinta dias, contados do recebimento dos autos, e prorrogáveis por justificação explícita - artigo $56, \S 1^{\circ}$, c/c artigo 59 da Lei 9.784/99.

Nos processos administrativos em que foram aplicadas sanções cabe, a qualquer tempo, revisão, a pedido ou de officio, desde que surjam fatos novos ou circunstâncias relevantes, capazes de justificar a inadequação da sanção aplicada - artigo 65 da Lei 9.784/99.

No processo administrativo revisional, contudo, não poderá haver agravamento da sanção - parágrafo único do artigo 65 da Lei $9.784 / 99$.

\subsection{Recurso - Revogação na Lei $9.784 / 99$}

Ao julgar o processo administrativo, a Administração manifesta entendimento sobre o padrão de legalidade que baliza o interesse em disputa. Portanto, é inadmissível que a mudança unilateral de opinião possa desconstituir o que foi definido, sob o crivo do contraditório e a observância do devido processo legal. A ocorrência de ilegalidade, na decisão processual, só poderá autorizar a busca do desfazimento da revisão do processo administrativo, pela via processual, com fundamento no contraditório e ampla defesa.

Por outro lado, nos termos do artigo 53 do mesmo diploma reitor do processo administrativo, no âmbito da Administração Pública Federal, a Administração deve anular seus próprios atos, quando eivados de vício de legalidade, e pode revogá-los por motivo de conveniência ou oportunidade, respeitados os direitos adquiridos.

\section{Prazos para interposição de recurso}

O recurso deverá ser interposto junto à autoridade que proferiu a decisão, no prazo de dez dias, contados a partir da ciência ou decisão ou divulgação oficial da decisão recorrida - artigo 59, caput e 66 da Lei 9.784/99.

\subsection{Prazos Processuais no Direito Brasileiro}

Os prazos começam a correr a partir da cientificação oficial, excluindo-se o dia do começo e incluindo-se o do vencimento, salvo se não houver expediente na repartição ou se for encerrado antes da hora normal; caso em que prorrogar-se-ão para o primeiro dia útil seguinte - artigo 66 , e $\S 1^{\circ}$ da Lei $9.784 / 99$. Os prazos expressos em dias contam-se de modo contínuo - artigo $66, \S 2^{\circ}$. Os prazos fixados em meses ou anos contar-se-ão de data a data e, se no mês de vencimento não houver dia equivalente ao do início do prazo, tem-se como termo o último dia do mês $\S \S 2^{\circ}$ e $3^{\circ}$ do artigo 66 da Lei $9.784 / 99$. Prazos esses que se assemelham aos dos artigos 178, 184 e 240 do Código de Processo Civil, com as devidas alterações propostas pelo mesmo diploma.

Interessante destacar que a Lei Federal, em seu artigo 23, caput, prevê que a prática de atos processuais se dê, apenas e tão-somente, em dias úteis, na sede da repartição pública em que tiver trâmite o processo. 
A fluência do processo recursal é contínua, uma vez que prazos processuais não se suspendem - artigo 67 -, embora o parágrafo $2^{\circ}$ do artigo 59 da Lei $9.784 / 99$ admita a prorrogação por dez dias, ante justificativa explícita do recorrente, que deverá requerer prorrogação, antes da consumação para, então, oferecer recurso no prazo assinalado:

a) “Inexistindo disposição específica, os atos do órgão ou autoridade responsável pelo processo e os atos administrativos que dele participem devem ser praticados no prazo de cinco dias, salvo motivo de força maior" - artigo 24 -, sendo cabível a prorrogação até o dobro, mediante comprovada justificação - parágrafo único do artigo 24.

b) As intimações, em geral, e, especificamente, de prova ou diligência ordenada serão feitas com antecedência mínima de três dias úteis - artigos 26 e 41 .

c) O prazo para os órgãos consultivos emitirem parecer sobre quando devam ser obrigatoriamente ouvidos, salvo norma especial ou comprovada necessidade de prazo maior - artigo 42 - é de 15 dias, no máximo. Tratando-se de parecer obrigatório e vinculante, o processo não terá seguimento até sua apresentação, responsabilizando-se quem deu causa ao atraso; se obrigatório, mas não vinculante, o processo poderá prosseguir e ser decidido, sem prejuízo da responsabilidade de quem se omitiu no atendimento $-\S 1^{\circ}$ e $2^{\circ}$ do artigo 42 .

d) O prazo para o interessado manifestar-se, após o encerramento da instrução do processo, é de dez dias; salvo se houver outro prazo legalmente fixado - artigo 44.

e) O prazo para a Administração decidir o processo administrativo é de trinta dias, a partir do encerramento da instrução, salvo prorrogação por igual período, expressamente motivada - artigo 49 .

f) O prazo para o interessado interpor recurso administrativo à autoridade que proferiu a decisão administrativa, salvo disposição legal específica diversa, é de dez dias, contados a partir da ciência ou divulgação oficial da decisão recorrida - artigo $59, \mathrm{c} / \mathrm{c}$, artigo $56, \S 1^{\circ}$.

g) Interposto o recurso, a autoridade competente deverá intimar os demais interessados, no prazo de cinco dias, para que apresentem as alegações - artigo 62 .

h) O prazo em que a autoridade que proferiu a decisão recorrida dispõe para reconsiderá-la é de cinco dias; findos os quais, não o fazendo, elevará o processo à autoridade superior $-\S 1^{\circ}$ do artigo 56 .

i) O recurso administrativo, se a lei não fixar prazo diferente, deverá ser decidido no prazo máximo de trinta dias, o qual poderá ser prorrogado ante justificativa explicita $-\S 2^{\circ}$ do artigo 59.

j) O direito da Administração de anular atos administrativos dos quais decorram efeitos desfavoráveis aos administrados, decai em cinco anos, contados da data em que foram praticados; salvo se comprovada má fé, e, em caso de efeitos patrimoniais contínuos, o prazo de decadência contar-se-á da percepção do primeiro pagamento - artigo $54, \S 1^{\circ}$, conforme BANDEIRA DE MELLO ${ }^{29}$.

29 BANDEIRA DE MELlo, Celso Antônio. Curso de Direito Administrativo. 14 ed. São Paulo: Malheiros Editores. 2002. p. 463/464. 


\subsection{Prazos no Direito Argentino}

No Direito Argentino, os prazos são regulados em dias úteis, administrativos - artículo 1, inciso "e", da Ley 19.549. Computam-se os dias em que a Administração concede atenção ao público - de segunda à sexta-feira —, excetuando-se feriados, dias não úteis, não laborais para a Administração. Deve-se entender dia como "o intervalo que corre da meia noite a meia noite" - artigo 24 do Código Civil.

O prazo determinado em dias é contado desde o dia seguinte ao da notificação do ato que o dispõe - artigo $1^{\circ}$, inciso "e", ap. 3. LNPA. Começa a correr à meia noite do dia útil seguinte àquele da notificação - artigo 24 do Código Civil. Se o ato foi notificado em dia não útil, podem apresentar-se duas situações:

a) se houvera determinado, previamente, o dia para efetuar a notificação artigo $1^{\circ}$, inciso " $\mathrm{e}$ " LNPA e artigo $2^{\circ}$ do Código Civil Argentino. Nessa hipótese, o prazo será computado desde o dia útil seguinte;

b) se não houvera determinado tal dia, hipótese em que a notificação será tida como efetuada no dia seguinte, o transcurso do prazo iniciará no dia útil subseqüente àquele da notificação irregular.

Para GORDILLO ${ }^{30}$, o resultado é irrelevante se a notificação for efetuada em dia não útil, uma vez que o prazo começa a correr, igualmente, e no dia útil seguinte.

Considerando que a Administração não atende ao Público durante vinte e quatro horas, o artigo 25 do Decreto Regulamentador $1.759 / 72$ (RLNPA) e a reforma ao regulamento instituída pelo Decreto $1.883 / 91$ (RR) estabeleceram a possibilidade de que os interessados apresentem requerimentos nas duas primeiras horas úteis, administrativas, do dia seguinte.

$\mathrm{Na}$ etapa recursiva, a mera apresentação do pedido de vista suspende o curso dos prazos - artigo 76 do Decreto 1.759/72, do Regulamento da Lei Nacional de Procedimento Administrativo (RLNPA). São os seguintes os prazos para interposição de recurso: Recurso de Reconsideración - dez dias, artigo 84 do Regulamento; Recurso de Reconsideración: trinta dias, artigo 86 do Regulamento; Recurso de Apelação: cinco dias, artigo 87, inciso "a" do Regulamento; Resolución por acto interlocutório: quinze dias, artigo 87, inciso "a" do Regulamento e trinta dias, se o ato for definitivo, artigo 87, inciso " $b$ " do Regulamento; Recurso jerárquico e de alzada: interposição no prazo de quinze dias, artigos 90 e 98 do Regulamento; Resolución: sessenta dias, artigo 99 do Regulamento; Recurso de Revisión: interposição de dez dias, se tratar-se de contradições na parte dispositiva da sentença e em outros casos, de trinta dias, artigo 22 da lei 19.549, LNPA: Reclamação Administrativa: noventa dias para a decisão e quarenta e cinco dias para o pronto despacho, artigo 31 da lei 19.549, LNPA, segundo FIORINI ${ }^{31}$.

30 GORDILLO, Agustin. Tratado de Derecho Administrarivo. [s.1]:[s.e]. t. 4.1. Cap. VIII. p. 19.

31 FIORINI, Bartolomé A. Derecho Administrativo. 2 ed. Buenos Aires: Abeledo Perrot. t. II. 1997. p. 523-24. 
Portanto. o tempo opera limites que o legislador impõe à Administração para prevenir prolongamento de inatividade ou para prevenir a antecipação de condutas face aos interesses do administrado.

\section{Conclusões}

Recursos administrativos são aqueles que se iniciam, desenvolvem e esgotam nas instâncias administrativas, sem vinculação com a função judicial. Compreendem os recursos matéria processual que permite, por meio das vias administrativas, aos administrados impugnarem os vícios existentes em atos administrativos e, também, no próprio procedimento.

Assim, os recursos administrativos são interpostos contra atos de particulares, praticados em face de interesses específicos da Administração Pública. Inquinando $o$ ato de vício de legalidade, o recorrente postula sua reforma para que seja restaurada a legalidade.

Por outro lado, é cabível o recurso com fundamentos em matéria de mérito administrativo, em que o recorrente, por meio do pedido de revisão do ato, solicita à autoridade superior alteração do ato ou conduta, objeto do recurso, provando que a revisão não afetará o interesse público e beneficiará o administrado.

O Administrador, nesse tipo de recurso, atuará em seu poder discricionário, podendo acolher ou rejeitar o recurso.

Sustenta-se que o recurso administrativo é um direito de sujeitos, que integra a garantia constitucional de defesa. É o meio estabelecido pelo direito objetivo para que os atingidos por um ato administrativo, na esfera de direitos ou interesses, mediante a interposição de um ato ou requerimento, exerçam o direito de que a Administração o reveja, na esfera administrativa, emanando novo ato administrativo.

Os recursos administrativos fundamentam-se nas prerrogativas da Administração de revisarem de ofício seus próprios atos, evitando-se uma possível atuação jurisdicional.

A lei brasileira confere legitimidade para recorrer às organizações e associações representativas, no tocante a direitos e interesses coletivos, e aos cidadãos ou associações representativas, quanto a direitos ou interesses difusos.

Quanto aos efeitos da interposição de recursos administrativos podem ser examinados sob o aspecto do ato, o objeto de impugnação, e sob o aspecto das atribuições conferidas pelo órgão julgador.

Tanto no direito brasileiro como no argentino, a regra geral não suspende a execução do ato. Em determinados casos excepcionais, há previsão normativa sobre o efeito suspensivo na execução do ato pela mera interposição de recurso, conferido pelo regulamento argentino que concede a suspensão transitória total ou parcial, da execução do ato impugnado, sempre que a mesma possa causar ao recorrente danos graves e que a mencionada suspensão não acarrete perturbação grave aos interesses gerais e aos direitos fundamentais de terceiro.

Texto similar encontra-se consagrado na Lei Federal 9.784/99, segundo a qual a Administração poderá, de ofício ou a pedido da parte e mediante decisão funda- 
mentada, suspender a execução por razōes de interesse público ou para evitar prejuízos graves ao interessado.

Não estabeleceu a Lei 9.784/99 norma de processo administrativo, como "processo contencioso administrativo", da mesma forma que ocorreu nos países estrangeiros, nem os tribunais ou "órgãos de julgamento" administrativos ligados ao Poder Judiciário. Esse instituto não existe no Direito Brasileiro. Relaciona-se ao que, usualmente, é denominado de jurisdição administrativa.

O Direito Argentino admite o contencioso administrativo, denominado de recursos judiciais diretos. São aqueles interpostos, diretamente, pelo particular contra decisões administrativas. Constituem-se remédios perante a autoridade judicial, representada quase sempre por um tribunal de apelações. São interpostos em sede administrativa e encaminhados, diretamente, em sede judicial para decisão, devendo tramitar e revolver, em sede judicial, para sua decisão - inciso "b", do artigo 25 , da Lei 19.549.

Quanto ao esgotamento das vias administrativas para ingresso judicial não parece ser óbice ao imediato acesso à esfera jurisdicional, se o caso exigir. Mas é desejável o prévio esgotamento da via administrativa porque a ampla discussão quanto à produção do ato administrativo, em sede não jurisdicional, pode facilitar o controle jurisdicional daquele ato; o que seria inconcebível sem o prévio processo.

O procedimento administrativo é pressuposto da ação processual administrativa no Direito Argentino, no qual o recurso administrativo ocupa lugar preponderante.

O esgotamento da via administrativa é considerado um privilégio da administração, que permite ao particular recorrente ver seu direito reconhecido, sem necessidade de recorrer à via judicial.

Os procedimentos administrativos no texto da lei Argentina são princípios básicos que asseguram aos interessados as garantias constitucionais do devido processo legal, como requisitos essenciais da estrutura, validez e eficácia do ato administrativo.

Nesse mesmo entendimento, a Lei $9.784 / 99$ contempla os princípios da legalidade, finalidade, motivação, razoabilidade, proporcionalidade, moralidade, ampla defesa, contraditório, segurança jurídica, interesse público e eficiência.

No trâmite processual, estão incluídos os recursos administrativos que devem ser considerados como matéria da esfera das leis constitucionais, referentes aos Poderes Executivo e Legislativo.

O Recurso Administrativo representa direito dos sujeitos que pleiteiam a garantia constitucional de defesa. Consiste em direito público subjetivo diferente do qual pode-se valer o administrado para obter a revisão de ato administrativo, na esfera administrativa.

Pode-se dizer que o Recurso Administrativo é o ato pelo qual o administrado, mediante interposição, exerce o direito de reconsideração de novo ato administrativo, na esfera administrativa.

Somente é possível pensar em realizar o princípio democrático quando e onde o administrado puder participar da concretização efetiva da administração. Para isso, é imprescindível que se assegure ao cidadão postular junto à Administração os princípios específicos do processo administrativo, previstos no artigo $2^{\circ}$ da Lei 
9.784/99. bem como ter ciência da tramitação dos processos administrativos, na condição de interessado, e vistas nos autos, obter cópias de documentos e conhecer as decisões proferidas. Além de ser intimado dos atos do processo e, se necessário, apresentar provas.

Conclui-se que os recursos administrativos podem decidir tanto para defender um direito, em sentido estrito - recurso subjetivo - , como para defender um interesse legítimo - recurso objetivo. O recurso administrativo é um direito dos sujeitos, que pleiteia a garantia constitucional de defesa.

Por outro lado, se o requerente não for parte da relação jurídica e nem afetado pela decisão proferida, no bojo do processo, e a lei não previu recurso para tal hipótese, mas, se o requerente tem interesse, apenas como cidadão, em impugná-la, poderá dirigir-se à autoridade competente para apreciar a matéria. É a prerrogativa de manifestação do direito de petição, previsto no artigo $5^{\circ}$, XXXIV da Constituição Republicana, que se denomina Representação.

A doutrina classifica os recursos administrativos em recursos hierárquicos próprios e impróprios, que se apresentam sob as modalidades: representação, reclamação e pedido de reconsideração.

Distingue-se, na Súmula 473 (STJ), a anulação e a revogação do ato administrativo. Ambas pertencem ao gênero da invalidação do ato administrativo e ocorrem quando há inconveniência. inoportunidade ou ilegalidade no ato.

A revogação do ato administrativo decorre de inconveniência para a Administração: porém, o ato é legal e perfeito. Somente a Administração pode fazê-lo, não cabendo ao Judiciário, que, apenas, pode anular o ato; assim como a Administração, com base em ilegalidade ou ilegitimidade do ato.

A revisão de oficio dos atos administrativos pela Administração constitui uma de suas principais prerrogativas - a autotutela.

No Direito Argentino, o regulamento dos procedimentos administrativos dispõe que os atos administrativos de alcance individual, bem como os de alcance geral podem ser impugnados, por meio de recursos administrativos. Fundam-se em razões vinculadas à legalidade, oportunidade, mérito e conveniência do ato impugnado, em prol do interesse público.

Conforme o disposto na Lei 19.549, regulamentada pelo Decreto 1.759/72, com as ulteriores alterações, os recursos são: Reconsideração - artigo 84 a 88, RPA; Hierárquico - artigos 89, 90, 91, 92 e 93 do Decreto 1.759/72, RPA; Alçada artigo 94 a 98 do Decreto 1.759/72, RPA; Revisão art 22 da Ley 19.459. São consideradas, ainda, outras vias administrativas, como a Queixa - artigo 71; Retificação de erros materiais - artigo 101: Aclaratória - artigo 102, RPA. Admite a doutrina e a jurisprudência, segundo o artigo 22 da Ley 19.549 da LNPA, o recurso extraordinário de revisão, se existirem contradições na parte dispositiva.

Interpostos os recursos, fixa-se os prazos, com o objetivo de conduzir a uma decisão juridicamente correta, no menor período de tempo possível.

A ciência oficial ou cientificação oficial, como quer a lei, é o fato pelo qual o destinatário do prazo toma conhecimento, real ou presumido, do ato a ser praticado no processo, no respectivo período. 
Uma comparação entre o sistema argentino e o brasileiro permite constatar, em ambos, a maior amplitude dos prazos para recorrer, em algumas hipóteses, e a menor elasticidade dos prazos previstos para o pronunciamento dos órgãos públicos competentes, o que deve ser considerado pelos interessados como ponto positivo.

Na esfera administrativa do Direito Brasileiro, os prazos processuais não se suspendem, a não ser na hipótese de força maior, comprovada; diferentemente do Direito Argentino, que suspende o curso dos prazos, na etapa recursiva, com a meia apresentação do pedido de vista - artigo 76, RLNPA.

A importância da Lei $9.784 / 99$ para o desenvolvimento do direito administrativo brasileiro consiste na dupla perspectiva do direito interno, que constitui, no direito comparado, emergente direito de integração, resultante do Mercosul.

\section{Referências bibliográficas}

BANDEIRA DE MELLO, Celso Antônio. Curso de Direito Administrativo. 14 ed. São Paulo: Malheiros Editores Ltda. 2001.

BASTOS, Celso Ribeiro. Curso de Direito Administrativo. 2 ed. São Paulo: Saraiva. 1996

BEVILÁQUA, Clóvis. Teoria Geral do Direito Civil. Rio de Janeiro: Francisco Alves. 1955.

BIELSA, Rafael. Teoria General Del Procedimiento Administrativo. Buenos Aires: Ediciónes Depalma. 1981.

Derecho Administrativo. Buenos Aires: t. II. 1947.

BUENO, Cassio Scarpinella. Os recursos nas leis de processo administrativo federal e paulista: uma primeira aproximação. In: SUNDFELD, Carlos Ari. As Leis do Processo Administrativo. São Paulo: Malheiros Editores. 2000. p. 190.

CARVALHO FILHO, José dos Santos. Manual de Direito Administrativo. 5 ed. Rio de Janeiro: Lumen Juris. 1999.

CASSAGNE, Juan Carlos. Derecho Administrativo. Buenos Aires: Abeledo - Perrot. T. II. 1996.

La Ley Nacional de Procedimientos Administrativos núm. 19549 en "El Derecho". Buenos Aires: 1992.

CODIGO do Consumidor Comentado. Arruda Alvim [et al] 2 ed. São Paulo: Editora Revista dos Tribunais. 1995.

CRETELLA JUNIOR, José. Prática do Processo Administrativo. 3 ed. rev. e atual. de acordo com a Lei 9.784/99. São Paulo: Editora Revista dos Tribunais. 1999.

Curso de Direito Administrativo. 8 ed. Rio de Janeiro: Forense. 1986.

DALLARI, Adilson de Abreu. Jornal do Advogado. [s.1]. Jun. de 1999. p. 25. $4^{a}$ coluna.

DELPIAZZO, Carlos E. Armonización jurídica e incorporación de normas comunes al Derecho interno en el Mercosur. In: De Derecho Administrativo. Buenos Aires: 1993. ano 5. n. 14. [s.p]. 
El procedimiento administrativo y las nuevas tecnologias de La información: In: Uruguaya de Derecho Administrativo y Político. Montevidéu: 1992. tomo VIII. n. 48.

. Alcances y limites del Derecho de la Integración: In: de Derecho Público. Montevidéu: 1998. n. 13. p. 45 e ss.

DI PIETRO, Maria Sylvia Zanella. Direito Administrativo. 3 ed. São Paulo: Atlas. 1993.

DROMI, Roberto. Derecho Administrativo. 4 ed. Buenos Aires: Ediciones Ciudad Argentina. 1995.

FRAGA, Gabino. Derecho Administrativo. 17 ed. México: Porrúa. 1977.

FIGUEIREDO, Lucia Valle. Curso de Direito Administrativo. 4 ed. São Paulo: Malheiros Editores. 2000.

FIORINI, Bartolomé A. Derecho Administrativo. 2 ed. Buenos Aires: Abeledo Perrot. 1997. t. II.

GARCIA. Oviedo. Derecho administrativo. Madrid: t. I. 1.959.

GARRIDO FALLA, F. Las tres crisis del derecho público subjetivo. Sevilha: 1954. GASPARINI, Diógenes. Direito Administrativo. 4 ed. São Paulo: Saraiva. 1995.

GONZÁLES PÉREZ. Los recursos administrativos. Madrid: 1960.

GORDILLO, Augustin. Tratado de Derecho Administrativo.[s.1].t. 4. [s.d].

GRECO FILHO, Vicente. Direito Processual Civil. 6 ed. São Paulo: Editora Saraiva. 3 v. 1999.

HAURIOU, Maurice. Précis de droit administratif 11. ed. Paris: 1938.

LASO, Enrique Sayagués. Tratado de Derecho Administrativo. Montevidéu: t. II. 1959.

LAZZARINI, Álvaro. Temas de Derecho Administrativo. São Paulo: Editora Revista dos Tribunais. 2000.

MARIENHOFF, Miguel. Tratado de Derecho Administrativo. Buenos Aires: Ed. Abeledo Perrot. t. I. 1995.

MARQUES, José Frederico. Manual de Direito Processual Civil. 2 ed. São Paulo: Saraiva. 1974.

MEDAUR, Odete. Direito Administrativo Moderno. 2 ed. São Paulo: RT. 1998.

MEIRELLES. Hely Lopes. Direito Administrativo Brasileiro. 18 ed.. São Paulo: Malheiros. 1993.

MUKAI, Toshio. A Lei do Procedimento Administrativo Federal. (Lei 9.784, de 1999). In: Revista Trimestral de Direito Público. São Paulo: Malheiros Editores. n. 27.1999.

Direito Administrativo Sistemático. [s.e]. São Paulo: Saraiva. 1999.

PONTES DE MIRANDA, Francisco Cavalcanti. Comentários ao Código de Processo Civil. 5 ed. Rio de Janeiro: Forense. 1996.

THEODORO JÚNIOR, Humberto. Curso de Direito Procesual Civil. Rio de Janeiro: Forense. 1999.

RIVERO, Juan. Droit Administratif. 8 ed. Paris: Dalloz. 1997.

SANTOS, Moacyr Amaral. Primeiras Linhas de Direito Processual Civil. 5 ed. São Paulo: Saraiva. 1977. 
SESIN, Domingo Juan. Administracion Pública. Actividade Reglada, Discrecional y Técnica - Nuevos Mecanismos de Control Judicial. Buenos Aires: Depalma. 1994.

STASSINOPOULOS, Epaminondas P. "Derecho comparado: uma nota sobre el procedimiento administrativo em Europa Ocidental" El procedimiento administrativo em el derecho comparado. Madrid: Editorial Civitas. 1993.

SUNDFELD, Carlos Ari \& MUÑOZ, Guilherme Andrés. As Leis do Processo Administrativo, Lei Federal 9.784/99 e Lei Paulista 10.177/98. São Paulo: Malheiros Editores. 2000.

VEDEL, Georges. Droit Administratif. 3 ed. Paris: Précis. Univ. France. 1976.

ZANCANER, Weida. Da Convalidação e da Invalidação dos Atos Administrativos. 2 ed. São Paulo: Malheiros Editores. 1996. 


\section{Revista de Direito Administrativo}

\section{Caio Tácito (organizador)}

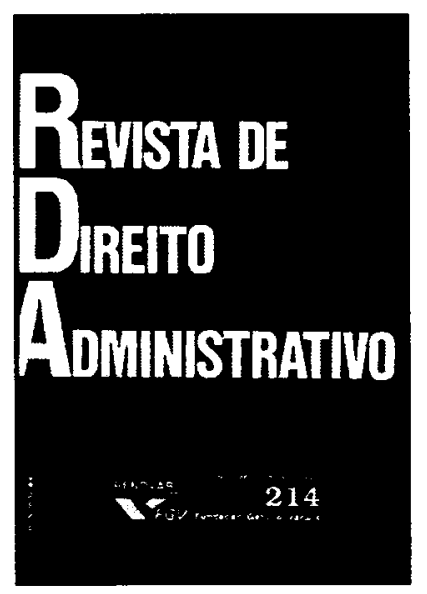

Com mais de meio século de publicação regular e ininterrupta, é a mais completa publicação no gênero. Em quatro números anuais oferece a mais completa e atualizada visāo do Direito Administrativo brasileiro, no plano da doutrina e pareceres, da jurisprudência administrativa, judicial e do Tribunal de Contas da Uniāo, e da Legislação Federal. Na sua especialidade, divulga temas de Direito Constitucional, Tributário ou Processual que interessam à interpretação e aplicação dos princípios e normas que regulam a atividade da Administração Pública Direta e Indireta.

Brochura Form. 16x23

Criada em 1945

\section{Revista de Direito Administrativo Seleção Histórica \\ Vários autores}

A presente coletânea reúne trabalhos publicados nos 150 primeiros números da Revista de Direito Administrativo, os quais, pela densidade do conteńdo, permanecem válidos como subsídios à doutrina do Direito Público. A seleçāo, se não esgota o lastro do passado, evidencia a perenidade de contribuiçōes antigas e propicia aos leitores de agora uma expressiva amostra da presença de autores falecidos que deixaram marca na história da ciência jurídica nacional.

Ref. 0102

Form. $16 \times 23$
Brochura 1996
467 págs.

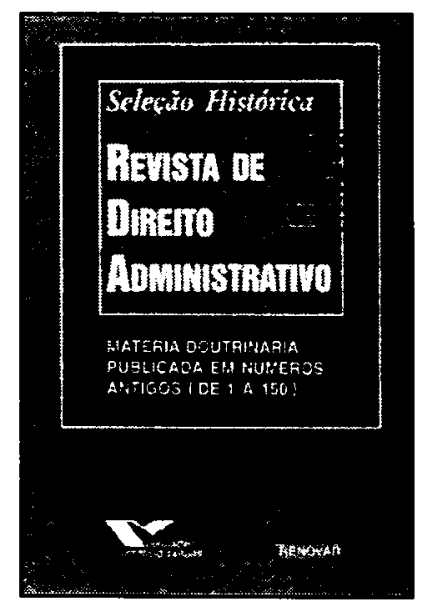

